DOI https://doi.org/10.18551/rjoas.2017-06.30

\title{
ANALYSIS OF REGIONAL FINANCE PERFORMANCE ON ECONOMIC GROWTH, POVERTYAND UNEMPLOYMENT IN WEST PAPUA PROVINCE, INDONESIA
}

\author{
Hay T.* \\ Master Program of Economic Science, University of Brawijaya, Indonesia \\ Pudjihardjo M., Syafitri W. \\ Faculty of Economics and Business, University of Brawijaya, Indonesia \\ *E-mail: terehay@gmail.com
}

\begin{abstract}
The present research intends to empirically reveal the relationship between regional finance performance and economic growth, poverty and unemployment in West Papua Province. Panel data regression model is applied to find out the effect of indicators composing Regional Finance Performance, namely Regional Real Income (RRI) Growth Ratio, Fit Ratio, Independence Ratio, RRI Effectiveness ratio and RRI Efficiency Ratio independent variables consisting of economic growth, poverty and unemployment.Panel data is combination betweentime seriesand (cross section).Simultaneous testing reveals no significant effects of RRI growth Ratio (X1), Fit Ratio (X2), independence ratio (X3), effectiveness ratio (X4), and efficiency ratio $(X 5)$ on economic growth $(Y 1)$. Partial testing reveals some significant effects of RRI growth ratio (X1) on economic growth (Y1), of Fit Ratio (X2) on economic growth (Y1), of independence ratio (X3) on economic growth (Y1), and of effectiveness ratio (X4) on economic growth (Y1).
\end{abstract}

\section{KEY WORDS}

Regional finance performance, economic growth, poverty.

The provision of decentralization and wide autonomy paves the way to regional governments for public interest-oriented regional finance administration. The economical, efficient, effective, transparent, accountable, and just management might drive economic growth of a certain region. A region's finance capability in autonomy era is measured by means of finance performance (Kuncoro, 2007). It is considered as the most crucial part of regional government administration. It is so due to the fact that regional governments can not enact their functions in a effective and efficient manner without a sufficient financial support. Thus finance is one indicator on which to find out regional governments capability to manage their region. Measurement to regional finance is instrumental to gauge transparency and accountability of regional budget. One instrument to do so is analysis of financial ratio against regional budgeting so-called APBD (Halim dan Kusufi, 2012).

APBD allocation for regional governments in West Papua during 2012-2014 pinpoints increasing trend. The largest is allocated by Teluk Bintuni regency in 2014 amounting to 2 . trillion 400 billion rupiahs, and the least is allocated by Maybrat regency amounting to 300 billion rupiahs. There is expectancy that this increase be accompanied by regional finance performance as a foundation for good governance. UU No. 33 of 2004 stipulates that Regional Real Income (income autonomously raised or RRI) is intended to provide authority for a regional government to finance its own development as it suits to regional autonomy and decentralization in order to accommodate more for regional potentials. Its success can be detected from increased public welfare reflected in increased per capita income and Human Development Index (HDI) (Swandewi, 2012).

Infrastructure development is related to regional finance management. Regional budgeting or APBD as a yearly finance planning plays determining role for regional economy, as it involves the scale of income, expense, and funding on which a government bases its decision making and development planning, future expense, and standard to evaluate 
performance and coordination of all sectors.

Unemployment in West Papua tended to be under national average during 2009-2014. For 2010-2012, unemployment in West Papua was above national average, which mostly had been due to the lack of skill and working experience. Since 2013,unemployment in West Papua is lower than national average, proving that increasing productive generation during 2013-2014 could be absorbed by working world available. The highest educated unemployment rate in 2014 was found in Teluk Bintuni regency which reached $8.25 \%$, and the lowest found in Teluk Wondama regency which reached $0.98 \%$.Economic growth should be followed by poverty alleviation, increased Human Development Index (HDI), and widened job opportunity.Research gapin the present research is the insertion the construct of fit ratio to find out whether regional government has striken an optimal and balanced point between direct and indirect expenses.

Based on the above background, statements of the problem are formulated as follows:

1. How are the effects of regional finance performance consisting of RRI Growth Ratio, Fit Ratio, Independence Ratio, RRI Effectiveness ratio and RRI Efficiency Ratio on economic growth in Regency/Municipality of West Papua Province?

2. How are the effects of regional finance performance consisting of RRI Growth Ratio, Fit Ratio, Independence Ratio, RRI Effectiveness and efficiency ratios on poverty in Regency/Municipality of West Papua Province?

3. How are the effects of regional finance performance consisting of RRI Growth Ratio, Fit Ratio, Independence Ratio, RRI Effectiveness and efficiency ratios on unemployment in Regency/Municipality of West Papua Province?

\section{THEORETICAL REVIEW}

Decentralization is a kind of transferring responsibility, authority and financial, personnel and other resources from central government to regional governments (Khusaini, 2006). Regulation No. 23 of 2014 at article 7 stipulates that Decentralization is the transfer of authority from central government to regional governments. Fiscal decentralization is the transfer of authority in fiscal sector (income and expense) from higher government to the lower. In theoretical review, decentralization will put government closer to its public (constituents) that leads to heightened efficiency.

Performance is a description on the extent to which a government has successfully achieved its objectives, goals, and missions and vision embodied in its planning strategy (Mahsun, 2012).Finance performance is the measurement performance applying finance indicators (Sularso dan Restianto, 2011). According to Halim (2001), to measure finance performance in government there are several regional budgeting-instruments available covering RRI growth Ratio, Fit Ratio, independence ratio, effectiveness ratio, and efficiency ratio.

Value for money is one definition for quality(Harvey \& Green, 1993). Quality money value looks at quality in terms of high result from investment. If the same results could be acquired from lower cost or better result could be obtained from the same cost, a consumer has a quality product or service. Government accountability emphasizes value for money.

\section{CONCEPTUAL FRAMEWORK}

To describe the flow of problems and expected results and test model, this research can be described as in Figure 1. follows:

Based on conceptual framework and previous researches, hypotheses are made as

$\mathrm{H}_{1}$ : It is assumed that Regional Finance Performance consisting of RRI Growth Ratio, Fit Ratio, Independence Ratio, RRI Effectiveness ratio and RRI Efficiency Ratio on economic growth in Regency/Municipality of West Papua Province 
$\mathrm{H}_{2}$ : How are the effects of regional finance performance consisting of (RRI) Growth Ratio, Fit Ratio, Independence Ratio, RRI Effectiveness and efficiency ratios on poverty in Regency/Municipality of West Papua Province?

$\mathrm{H}_{3}$ : How are the effects of regional finance performance consisting of (RRI) Growth Ratio, Fit Ratio, Independence Ratio, RRI Effectiveness and efficiency ratios on unemployment in Regency/Municipality of West Papua Province?

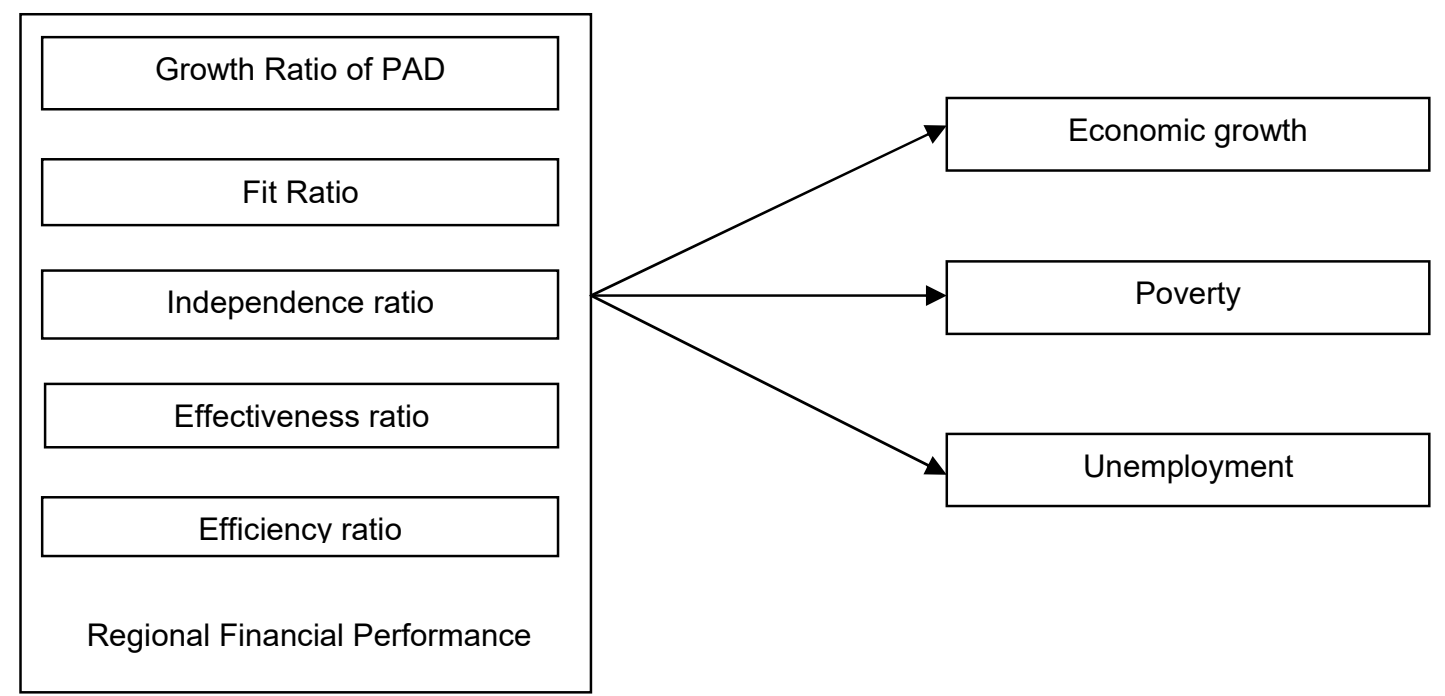

Figure 1 - Conceptual Framework

\section{METHODS OF RESEARCH}

Province of West Papua consists of 12 regencies and 1 municipality, but the present research uses 10 regencies and 1 municipality as its sample. The exclusion of 2 other regencies (MountainsArfak regency and Manokwari Selatan regency) is due to the fact that they just have had their status as New Autonomy Region (NAR) in 2013.The present research applies secondary data from BPS (Badan Pusat Statistik or Governmental Office for Statistics), Direktorat Jenderal Perimbangan Keuangan (DJPK), and the Government of West Papua Province. Panel data regression model is applied to find out the effect of indicators composing Regional Finance Performance, namely Regional Real Income (RRI) Growth Ratio, Fit Ratio, Independence Ratio, RRI Effectiveness ratio and RRI Efficiency Ratio independent variables consisting of economic growth, poverty and unemployment.Panel data is combination between time series and cross section.

\section{RESULTS AND DISCUSSION}

Simultaneous testing brings up $F_{\text {stat }}=8.986$ with probability 0.000 . It shows that probability <level of significance $(\alpha=10 \%)$. It means that there is no significant simultaneous effects of RRI growth Ratio (X1), Fit Ratio (X2), independence ratio (X3), effectiveness ratio (X4), and efficiency ratio on economic growth (Y1). Based on the results, RRI growth Ratio has a significant and negative effect on poverty. It is consistent with previous assumption and research of Haryanto (2007). The negative relationship implies that the increased RRI growth Ratio significantly reduce poverty. RRI is optimally allocated to direct expense covering program implementation for poverty alleviation such as health, education, and transportation infrastructures, a conducive business climate, and others.

The increased fit ratio significantly reduces poverty. It reveals that performance of regional governments in west Papua in allocating finance to direct expense has been optimal in line with well-planned programs that lead to increased public welfare. The programs include Infrastructure, opening access to isolated areas, multiplying job opportunity and 
ensuring a conducive business climate that attract many investors. All of these contribute to the reduced poverty in West Papua.

The increased independence ratio significantly reduces poverty. This is in line with Abudzar's research (2010) that regional independence have a significant effect on decreased poverty in Middle Java. Regional Independence allows regional government to make a more suitable decision in allocating budget as local needs.

This condition proves that regional governments in West Papua have managed to finance themselves for administration, development and service delivery to public, where the finance comes from Regional Real Income.

Negative relationships prove that the increased effectiveness ratio significantly reduces poverty in West Papua. Increased effectiveness in making us of finance with greater results has determinant impact on poverty alleviation through less costly programs such as empowerment for the unfortunates, aid and social assurance programs, social welfare rehabilitation and social service.

Another negative relationship proves that increased efficiency ratio in regional finance reduces poverty. It shows that a regional government plays a significant part in raising income which is far larger than their expense target. This allows them to finance all programs and activities material in poverty alleviation in west Papua.

Partial testing of Regional Real Income (RRI) Growth Ratio (X1) on economic growth (Y1) brings up t stat $=1.895$ with probability $=0.064$. The results reveal that probability<level of significance $(\alpha=10 \%)$. It means that there is a significant partial effect of Regional Real Income (RRI) Growth Ratio on economic growth (Y1).Regional governments have managed to retain and even magnify regional real income (Halim, 2006), supporting expectation that it has a bigger effect on economic growth of west Papua in the future.

Partial testing of fit ratio (X2) on economic growth (Y1) brings up t stat $=3.465$ with probability $=0.001$. It shows that probability<level of significance $(\alpha=10 \%)$. It means that there is a significant partial effect of fit ratio (X2) on economic growth (Y1). This is congruent with previous assumption and researches of Zikriah (2008) and Yushkov (2015). This positive relationship proves that the increased fit ratio (direct expense) leads to increased economic growth in West Papua. The fact supports this relationship that during the conduct of research, almost have regions in West Papua enjoyed increased direct expense.

Partial testing of independence ratio $(\mathrm{X} 3)$ on economic ratio $(\mathrm{Y} 1)$ brings up $t$ stat $=$ 1.809 with probability $=0.077$. The result shows probability<level of significance $(\alpha=10 \%)$. It means that that there is a significant partial effect of independence ratio (X3) on economic growth (Y1).Theory put forward by Tiebout (1961) lends support for this. The gist is that fiscal decentralization systems where regional governments play a more decisive part that central government in public service delivery provide a chance to prove ability to raise a larger income. This ability assures independence.

Partial testing of effectiveness ratio $(\mathrm{X} 4)$ on economic growth $(\mathrm{Y} 1)$ produces $\mathrm{t}$ stat $=$ 2.050 with probability $=0.046$. It shows that probability<level of significance $(\alpha=10 \%)$. It means that there is a partial significant effect of effectiveness (X4) on economic growth (Y1).It reflects regional government's ability to make use of income optimally to finance programs and activities estimated to have a direct impact on public welfare. By doing so, regional governments in West Papua removes all business obstacles, heighten public's awareness of tax, conducive business climate that attracts investment important for increasing economic growth.

Partial testing of efficiency ratio (X5) on economic growth (Y1) produces t stat $=2.016$ with probability $=0.049$. It reveals that probability<level of significance $(\alpha=10 \%)$. It means that there is a partial significant effect of efficiency ratio (X5) on economic growth (Y1). This positive relationship proves that the increased efficiency ratio leads to economic growth. It might be due to the income ins larger than the expense. Because of this efficiency, the surplus can be allocated to another expense posts that may drive economic drive such as education, health, infrastructure (high-ways, bridges, trasportation, hospitals, schools, markets) and other supporting infrastructures sustaining public's economic faculty. 


\section{CONCLUSION AND SUGGESTIONS}

The increased real income has an effect on regional governments in allocating their budgets on development programs of strengthening stable economic growth including sustaining tax awareness, retribution, a good feedback from society toward development financed from taxpayers money, people stable purchasing power, high sector contribution priority sector (gas oil) on PDRB, conducive business climate that strongly attracts investors. The condition reveals that regional governments in west Papua have managed to maintain and heighten their success in terms independent real income.

Secondly, the larger income compared to the expense underlines the existence of effectiveness and absence of inefficiency, and as the result the surplus can be allocated to the programs that have direct impacts on poverty alleviation.

Finally, regional governments in West Papua have managed to finance themselves their governmental operations, development and service delivery from real income which are oriented to poverty alleviation.

For effectiveness ratio on unemployment, regional governments must able to exploit real income to develop infrastructures, to procure public structures that support productivity and sectors' added values that can provide job opportunity including agriculture, farming, maritime, fishery, gas and oil.

Moreover, the authors suggest for future research to include more relevant construct in terms of economic growth, poverty and unemployment, for instance investment, with different research time range and wider research location.

\section{REFERENCES}

1. Abudzar. 2010. Ekonomi Zakat Sebuah Kajian Moneter dan Keuangan Syariah. Translated by M.A.A. Karim, Iqtishaasiyaatu az-zakat wa'tibaaraatus siyaasah, 1991. Jakarta: Rajawali Press

2. Halim, A. 2001. Manajemen Keuangan Daerah. Yogyakarta: UPP Akademi Manajemen Perusahaan YKPN.

3. Halim, A. 2006. Akuntasi SektorPublik. Yogyakarta: UPP Akademi Manajemen Perusahaan YKPN.

4. Halim, A. \& Kusufi, S. 2012. Akuntansi Sektor Publik: teori, konsep dan aplikasi. Salemba Empat: Jakarta.

5. Harvey, L. \& Green, D. 1993. Defining Qualty. Assesment and Evaluation in Higher Education, 18 (1), 9-34.

6. Khusaini, M. 2006.Ekonomi Publik: Desentralisasi Fiskal dan pembangunan daerah. Malang: BPFE UB

7. Kuncoro, H. 2007. Fenomena Flypaper Effect Pada Kinerja Keuangan pemerintah daerah Kota dan Kabupaten di Indonesia. Simposium Nasional Akuntansi X. UNHAS Makassar, 26־27 Juli 2007.

8. Mahsun M. 2012. Pengukuran Kinerja Sektor Publik. Yogyakarta : BPFE - UGM.

9. Sularso, H. \& Restianto, Y.E. 2011. Pengaruh Kinerja Keuangan Terhadap Alokasi Belanja Modal dan Pertumbuhan Ekonomi Kabupaten/Kota di Jawa Tengah. Media Riset Akuntansi, Vol.1 No.2: 109 - 124.

10. Swandewi. 2012. Pengaruh Dana Perimbangan dan Kemandirian Keuangan Daerah Terhadap Keserasian Anggaran Dan Kesejahteraan Masyarakat Pada Kabupaten/Kota Di Provinsi Bali. E-Jurnal Ekonomi dan Bisnis Universitas Udayana, 3.7 (2014) :356-376.

11. Tiebout C.M. \& Warren R. 1961. The Organizational of Government in Metropolitan Areas: A Theoretical Inquiry.

12. Yushkov, A. 2015. Fiscal Decentralization and Regional Economic Growth: Theory, Empirics and the Russian Experience.

13. Zikriah. 2008. Pengaruh Belanja Modal Pemerintah dan Produk Domestik Regional Bruto terhadap Penduduk Miskin di Aceh. Jurnal Ekonomi Banda Aceh, FEB-Universitas Syiah Kuala. 